\title{
EVALUASI APLIKASI E-COMMERCE PADA SEKTOR PENJUALAN BUKU ONLINE DARI PERSPEKTIF KONSUMEN DI INDONESIA MENGGUNAKAN EXTENDED WEB ASSESSMENT METHOD (EWAM)
}

\author{
Andi Susilo", Riri Satria ${ }^{2}$, Widijanto Satyo Nugroho ${ }^{3}$ \\ ${ }^{1}$ Program Studi Teknik Informatika, Fakultas Teknologi Informasi, Universitas Respati Indonesia \\ Jl. Bambu Apus I, No. 3 Cipayung Jakarta 13890 \\ Telp. (021) 8454731, Faks. (021) 8457628 \\ ${ }^{2,3}$ Program Studi Magister Teknologi Informasi, Fakultas Ilmu Komputer, Universitas Indonesia \\ d.a. Gedung Pusat Ilmu Komputer-UI \\ Jl. Salemba 4 Jakarta 10430 \\ Telp. (021) 3106014, Faks. (021) 3102774 \\ E-mail:as@urindo.ac.id,rrsatria@cs.ui.ac.id,wnugroho@cs.ui.ac.id
}

\begin{abstract}
ABSTRAKS
Di dunia Internet, banyak situs e-commerce memiliki tampilan grafis yang menarik, isi terorganisasi dengan baik, namun belum tentu situs-situs tersebut menarik pengunjung untuk datang kembali secara teratur dan melakukan transaksi bisnis. Banyak perusahaan dan institusi terkejut menemukan bahwa alokasi anggaran biaya yang besar tidak selalu menjamin keberhasilan bisnis melalui Internet. Salah satu alasan mengapa konsumen potensial akhirnya tidak melanjutkan kepada tahapan pembelian adalah karena sebuah situs web memiliki tingkat fokus kepada konsumen yang rendah. Extended Web Assessment Method (EWAM) adalah sebuah instrumen untuk membuat pernyataan umum pada kualitas situs web komersial dari perspektif konsumen. Dalam studi ini peneliti mengevaluasi empat situs web aplikasi e-commerce penjualan buku online di Indonesia dan menggunakan situs web amazon.com sebagai Standar De Facto sebagai pembanding. Riset ini menemukan bahwa situs-situs web penjualan buku online di Indonesia yang dievaluasi belum memenuhi ekspektasi konsumen ditunjukkan dengan skor kurang dari satu $(<1)$ yaitu kutukutubuku.com (0.73), erlangga.co.id (0.67), gramediaonline.com (0.35), dan terakhir balaipustakaonline.com $(0.31)$.
\end{abstract}

Kata Kunci: e-commerce, metode, penilaian web, de facto

\section{PENGENALAN}

Berdasarkan hasil survei Internet World Stats (30 Juni 2009) Asia memperoleh peringkat pertama jumlah pengguna Internet di dunia yaitu 704.213.930 pengguna disusul Eropa yang menduduki peringkat kedua dengan 402.380.474 pengguna. Jumlah pengguna Internet di Indonesia pada tahun 2009 mencapai 25 juta pengguna dari populasi penduduk Indonesia yang jumlahnya 240.271.522 jiwa. Ini berarti untuk tahun 2009 penetrasi internet mencapai $10,4 \%$ dari populasi yang merupakan peningkatan hampir duabelas setengah kali dibandingkan dengan pengguna Internet tahun 2000 yang hanya berjumlah 2 juta pengguna.

Belanja online memiliki banyak keuntungan potensial bagi konsumen secara khusus dari sisi kenyamanan dan penghematan waktu (Leimstoll, Kurnia \& Schubert, 2005). Menurut Morganosky dan Cude (2000), Slonae (2000) bahwa penjualpenjual akan memperoleh keuntungan-keuntungan signifikan yang akan mengarah kepada penggunaan yang lebih efisien dari karyawan dan menyederhanakan pembangunan infrastruktur (Leimstoll, Kurnia \& Schubert, 2005). Bisnis yang dilakukan melalui Internet menjadi penting untuk diperhatikan terutama dari sisi perspektif konsumen guna menghasilkan nilai bisnis yang diharapkan organisasi/perusahaan.

Metode EWAM menilai situs web berdasarkan perspektif konsumen yang fokus kepada kategori Business to Customer (B2C) sehingga sesuai untuk penelitian yang kami lakukan.

\section{METODOLOGI}

\subsection{Desain Riset}

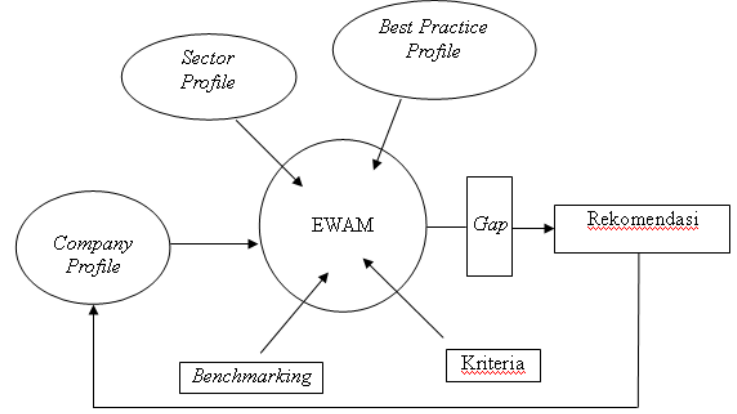

Gambar 1 Desain riset evaluasi aplikasi e-commerce

mengilustrasikan kerangka konseptual penelitian ini. Metode EWAM mengevaluasi tiga variabel yaitu Usefulness, Ease of Use, dan Trust. Ketiga variabel 
ini dipecah menjadi 26 kriteria dan dikelompokkan kepada fase-fase transaksi elektronik yaitu Information Phase, Agreement Phase, Settlement Phase, After-Sales Phase, ditambah dengan Community Component, dan Final Section (Schubert, 2003).

Setiap Company Profile (situs web) dievaluasi dan hasil penilaiannya dibandingkan dengan Best Practice Profile (situs web dengan skor tertinggi) dan Sector Profile (nilai rata-rata dari seluruh situs web yang diuji), Gap akan ditemukan dari hasil perbandingan profil terhadap profil terbaik dan ekspektasi konsumen, maka rekomendasi diperlukan untuk memperbaiki situs web dengan kinerja yang dinilai kurang baik.

\subsection{Metode Riset}

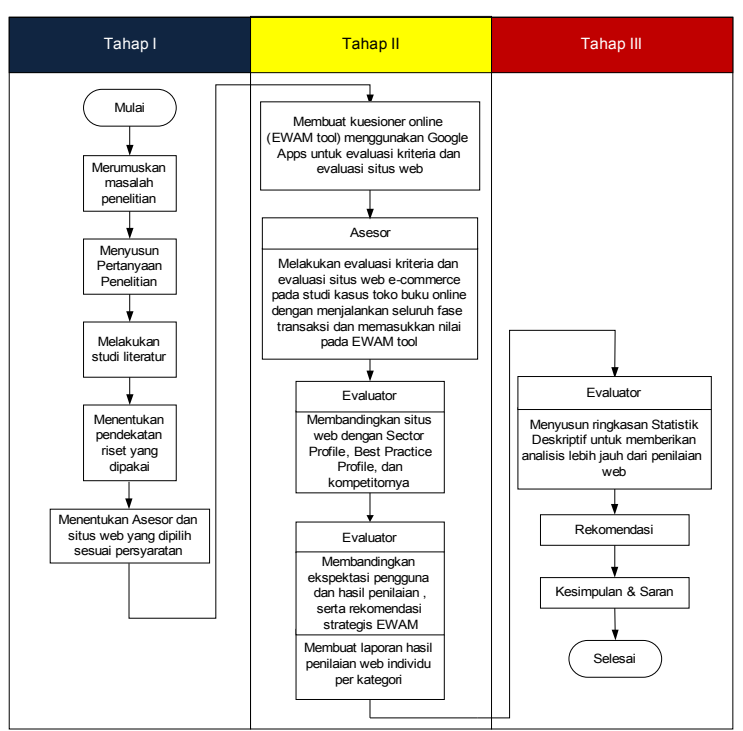

Gambar 2 Tahap-tahap pelaksanaan penelitian yang dilakukan

Penelitian ini dilaksanakan melalui tiga tahap seperti terlihat pada Gambar 2 yaitu

- Tahap I: Merumuskan masalah yang akan diteliti, melakukan studi literatur terkait dengan aspek-aspek yang akan diteliti, dan menentukan jumlah asesor yang akan menilai.

- Tahap II: Membuat instrumen kuesioner secara online terdiri dari formulir evaluasi kriteria dan formulir evaluasi situs web dari EWAM tool yang dibuat menggunakan Google Apps. Setiap asesor akan melakukan dua penilaian yaitu evaluasi situs web dan evaluasi kriteria. Setelah seluruh asesor melakukan penilaian maka peneliti mengambil data tersebut dari Google Docs.

- Tahap III: Melakukan analisis data secara lengkap dan membuat kesimpulan.

\subsection{Extended Web Assessment Method (EWAM)}

\subsubsection{Asumsi Dasar}

Metode EWAM dikembangkan pada tahun 2001 di Universitas Ilmu Terapan Basel, Swiss (Leimstoll, Kurnia \& Schubert, 2005) berdasarkan Metode Penilaian Web terdahulu yang dikembangkan pada permulaan tahun 1997 oleh Petra Schubert dan Dorian Selz di Competence Centre for Electronic Markets (CCEM), Universitas St. Gallen, Swiss bekerjasama dengan perusahaan-perusahaan rekanan (Selz dan Schubert, 1998. 1999; Schubert dan Selz, 2001). EWAM mengintegrasikan temuan-temuan dari Technology Acceptance Model (TAM) dan Theory of Reasoned Action (TRA) dan beberapa pendekatan-pendekatan alternatif berikut (Schubert, 2003):

- Desain kualitas dari situs-situs Web untuk ecommerce: evaluasi-evaluasi fortune 1000 webmaster;

- Dampak karakteristik-karakteristik situs Web yang diterima pada lalu lintas situs Web;

- Perfect Web pages;

- Web usage mining untuk evaluasi situs Web;

- GomezPro.com;

- JurisNET.

Schubert (2003) mengacu kepada analisis dan kategorisasi detail yang dilakukan oleh Totz et al. Berdasarkan artikel Totz et al., Schubert (2003) menyusun EWAM dalam kategori: (1) market focus (external visibility); (2) subjective (persepsi kualitas pelanggan); dan (3) attribute specific.

\subsubsection{Komponen-komponen EWAM}

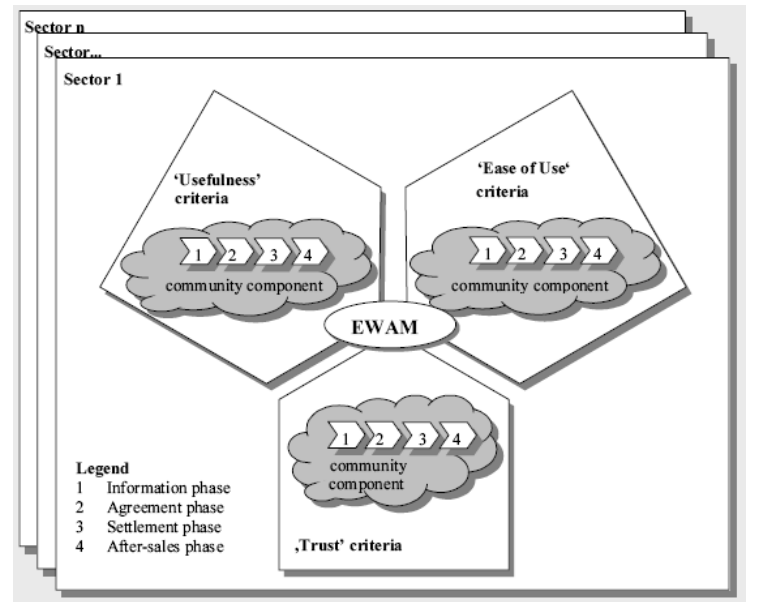

Gambar 3 Diagram Extended Web Assessment Method (EWAM)

Sumber: Schubert, 2003

Kombinasi EWAM dengan kategori-kategori Ease of Use, Usefulness, dan Trust diperlihatkan pada Gambar 3. Dimensi sektor "1..n" 
mengilustrasikan perluasan dari EWAM dengan profil-profil sektor dan mempertimbangkan perbedaan kriteria individual yang penting di dalam sektor-sektor ini.

\subsubsection{Peringkat Penting}

EWAM didasarkan kepada evaluasi ganda bagi setiap kriteria. Pertama, makna subyektif bagi sebuah atribut yang dideklarasikan oleh asesor. Kedua, evaluasi seluruh situs web di dalam sektor yang sama. Dalam kasus peringkat makna bernilai rendah ("--"), maka nilai evaluasi aktual (tahap kedua) hampir tidak diperlukan lagi.

\section{PENGUMPULAN DAN ANALISIS DATA}

\subsection{EWAM Tool}

EWAM tool merupakan kuesioner online yang dalam penelitian ini dibuat menggunakan Google Apps. Setiap asesor mengakses EWAM tool dengan mengetikkan URL: http://webatool.andipensil.com diikuti dengan melengkapi username dan password.

Ketika asesor mulai mengevaluasi, maka pertama kali asesor harus merekam Uniform Resource Locater (URL) dari situs web yang diuji dan menetapkan ke sektornya. Asesor harus memutuskan sebuah pernyataan positif atau negatif dengan nilainya masing-masing. Skala memiliki empat nilai $(++,+,-,--)$, alternatif nilai "n.a" (not applicable) bisa digunakan jika sebuah kriteria tidak relevan atau tidak tersedia dalam konteks tertentu. Evaluasi positif (negatif) akan mengarah kepada hasil positif (negatif). "Saya sangat setuju" (+2), "Saya setuju" $(+1)$, "Saya tidak setuju" $(-1)$, "Saya sangat tidak setuju" (-2). "N.a." bernilai nol (0) artinya diabaikan untuk kalkulasi lebih lanjut. Lima skala penilaian tersebut juga diterapkan pada penelitian evaluasi situs web e-commerce yang dilakukan oleh Merwe \& Bekker (2003).

\subsection{Analisis dan Persiapan Data}

Dalam analisis data, EWAM tool mendefinisikan tiga profil yang menggambarkan evaluasi yang mengandung arti dari setiap web yang akan diuji:

- Sector Profile: profil dari sektor yang relevan. Penjualan buku online adalah sektor yang dipilih pada riset ini.

- Company Profile: Profil dari situs web. Terdapat empat profil situs web yang diuji yaitu balaipustakaonline.com, gramediaonline.com, erlangga.co.id, dan kutukutubuku.com. Situs web amazon.com dijadikan Standar De Facto pada riset ini.

- Best Practice Profile: profil yang berkembang paling baik dalam sektor yang relevan. Profil yang dipilih adalah sesuai dengan hasil evaluasi.

\subsection{Laporan Penilaian Web Individu}

Berdasarkan kepada penilaian situs web, sebuah laporan penilaian web individu yang mengandung representasi grafis menghasilkan (Schubert dan Kurnia, 2004):

1. Ringkasan dari kriteria individu dan hasilhasilnya dalam fase-fase "Information Phase", "Agreement Phase", "Settlement Phase", "After-Sales Phase", "Community Component","Final Section", dan kalkulasi skor total.

2. Perbandingan situs-situs web (Company Profile) yang diuji dengan rata-rata sektor (Sector Profile) dan profil terbaik (Best Practice Profile) dalam analisis kuantitatif dan representasi grafis tanpa memperhatikan peringkat penting.

3. Perbandingan dalam bentuk grafik hasil-hasil dari enam kategori $(1,2)$ dengan peringkat penting.

4. Perbandingan seperti pada poin (2) diatas, namun dengan memperhatikan peringkat penting.

Schubert \& Dettling (2001) mengidentifikasikan tiga kelompok target yang berbeda yang akan memperoleh keuntungan-keuntungan dari laporan penilaian web individu yaitu:

- Internet vendor: perbandingan dari kualitas orientasi konsumen dari situs web dengan profil sektornya atau kompetitor langsung.

- Potential Internet Vendor: Meningkatkan kesadaran pentingnya mengetahui kriteriakriteria sukses dari situs-situs web e-commerce.

- Internet buyers/users: Menguji kualitas yang berorientasi kepada pelanggan dari situs web melalui pelanggan membeli secara online.

\section{STUDI EVALUASI SEKTOR TOKO BUKU}

Tabel 1 merangkum jumlah asesor yang menilai situs-situs web dalam studi ini. Selanjutnya evaluasi kualitatif oleh peneliti memperlihatkan kejelasan dan kebergunaan hasilnya.

Tabel 1 Situs-situs web dan jumlah asesor

\begin{tabular}{|l|c|}
\hline \multicolumn{1}{|c|}{ Situs web } & $\begin{array}{c}\text { Jumlah } \\
\text { Asesor }\end{array}$ \\
\hline www.amazon.com & 19 \\
\hline www.balaipustakaonline.com & 20 \\
\hline www.erlangga.co.id & 19 \\
\hline www.gramediaonline.com & 19 \\
\hline www.kutukutubuku.com & 20 \\
\hline
\end{tabular}




\subsection{Evaluasi Kriteria}

Tabel 2 Peringkat penting dari setiap kategori

\begin{tabular}{|l|c|}
\hline \multicolumn{1}{|c|}{ Fase } & $\begin{array}{c}\text { Peringkat Penting } \\
\text { (Jangkauan -2/+2) }\end{array}$ \\
\hline Information Phase & 1.47 \\
Agreement Phase & 1.45 \\
Settlement Phase & 1.35 \\
After-Sales Phase & 1.42 \\
Community Component & 0.74 \\
Final Section & 1.47 \\
\hline
\end{tabular}

Tabel 2 memperlihatkan ringkasan hasil evaluasi kriteria yang dievaluasi oleh 19 asesor. Seluruh asesor menyatakan penting kriteria pada 5 fase berturut-turut Information Phase (1.47) dan Final Section (1.47), Agreement Phase (1.45), After-Sales Phase (1.42), Settlement Phase (1.35), sedangkan Community Component (0.74) dianggap tidak terlalu penting oleh asesor.

\subsection{Hasil Evaluasi Situs Web berdasarkan Peringkat Penting}

Tabel 3 Rangkuman evaluasi situs web dengan peringkat penting

\begin{tabular}{|l|c|c|c|c|c|c|c|}
\hline \multicolumn{1}{|c|}{ Fase } & $\begin{array}{c}\text { Peringkat } \\
\text { penting }\end{array}$ & $\begin{array}{c}\text { Balaipustaka } \\
\text { online }\end{array}$ & exlangga & $\begin{array}{c}\text { Gramedia } \\
\text { online }\end{array}$ & BPP & DFS & SCP \\
\hline $\begin{array}{l}\text { Information } \\
\text { Phase }\end{array}$ & 1.47 & 0.46 & 0.90 & 0.45 & 0.87 & 1.43 & 0.82 \\
\hline $\begin{array}{l}\text { Agreement } \\
\text { Phase }\end{array}$ & 1.45 & 0.58 & 0.79 & 0.51 & 1.03 & 1.41 & 0.86 \\
\hline $\begin{array}{l}\text { Seftlement } \\
\text { Phase }\end{array}$ & 1.35 & 0.00 & 0.41 & 0.07 & 0.52 & 1.4 & 0.47 \\
\hline $\begin{array}{l}\text { Affer-Sales } \\
\text { Phase }\end{array}$ & 1.42 & 0.18 & 0.53 & -0.06 & 0.43 & 0.98 & 0.41 \\
\hline $\begin{array}{l}\text { Community } \\
\text { component }\end{array}$ & 0.74 & -0.27 & 0.25 & -0.35 & 0.25 & 0.63 & 0.10 \\
\hline Final Section & 1.47 & 0.48 & 0.71 & 0.72 & 0.88 & 1.53 & 0.86 \\
\hline Overall Score & $\mathbf{m a .}$ & $\mathbf{0 . 3 1}$ & $\mathbf{0 . 6 7}$ & $\mathbf{0 . 3 5}$ & $\mathbf{0 . 7 3}$ & $\mathbf{1 . 3 2}$ & $\mathbf{0 . 6 7}$ \\
\hline
\end{tabular}

BPP: Best Practice Profile, DFS: De Facto Standard, SCP: Sector Profile

Tabel 3 didasarkan pada Tabel 2 memperlihatkan ringkasan skor penilaian situs web berdasarkan peringkat penting. kutukutubuku.com memperoleh skor tertinggi (0.73) sehingga menjadi Best Practice Profile disusul oleh toko buku online berikutnya erlangga.co.id (0.67), gramediaonline.com $(0.35)$, dan terakhir balaipustakaonline.com (0.31) mendapatkan peringkat terendah. memperlihatkan rangkuman penilaian situs web berdasarkan peringkat penting. kutukutubuku.com memperoleh skor tertinggi sebagai situs web lokal, sedangkan balaipustakaonline.com menjadi situs web dengan performa terburuk.

Gambar 5 memperlihatkan lebih jauh rangkuman hasil evaluasi situs web per fase dengan peringkat penting. Amazon.com sebagai situs web aplikasi $e$ commerce Standar De Facto memperoleh skor tertinggi pada setiap fase. kutukutubuku.com memperoleh peringkat tertinggi dari situs web lokal yang diuji (Best Practice Profile) disusul erlangga.co.id, balaipustakaonline.com, dan gramediaonline.com mendapatkan nilai terendah berada di bawah rata-rata sektor.

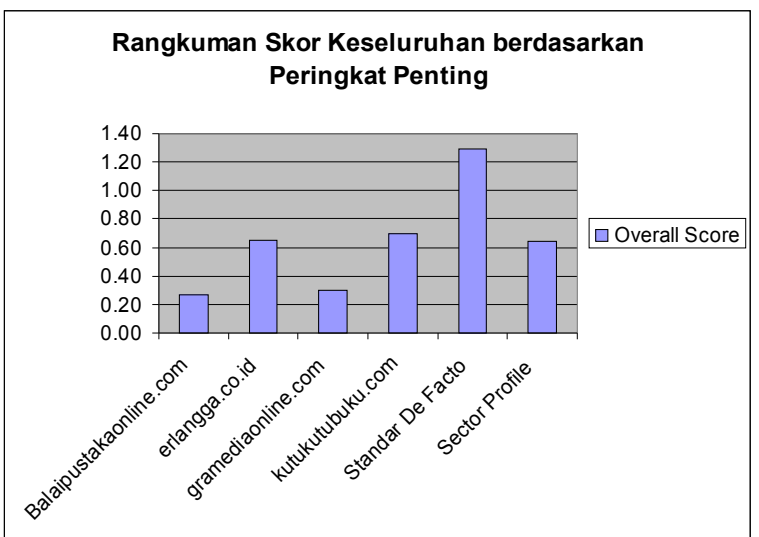

Gambar 4 Rangkuman penilaian situs web dengan peringkat penting

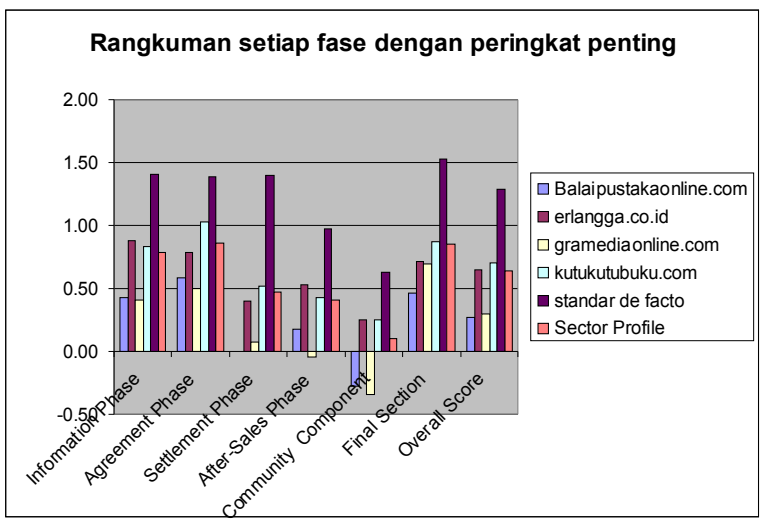

Gambar 5 Rangkuman penilaian toko buku online per fase dengan Peringkat Penting

Analisis kualitatif lebih jauh per fase akan diuraikan sebagai berikut:

- Pada Information Phase, kutukutubuku.com memperoleh penilaian yang baik untuk kriteria "Struktur Isi" (1.15) dan "Kuantitas Informasi" (1.20) artinya setiap asesor menilai penting kedua kriteria ini pada fase terkait. Pada kriteria "Kualitas Isi" kutukutubuku.com memperoleh nilai tertinggi (skor 1.20), kutukutubuku.com sangat perlu mempertahankan kriteria ini sebagai pelaku bisnis online murni. erlangga.co.id juga memperoleh skor yang tinggi pada tiga kriteria pertama "Kemudahan akses dari situs web dan produk-produknya" (skor 1.30), "Struktur Isi" (skor 1.21) dan "Kuantitas Informasi" (skor 1.21). Temuan juga menunjukkan bahwa kriteria 
"Sistem-sistem rekomendasi" tidak memuaskan bagi situs-situs web lokal.

- Pada Agreement Phase menurut asesor kedua kriteria dalam fase ini penting (skor 1.45). Balaipustakaonline.com dan erlangga.co.id memperoleh nilai yang sama pada kriteria "Model-model dan metode-metode penetapan harga" (B: 0.55, E:0.55). gramediaonline.com dan balaipustakaonline.com menerima nilai rendah pada kedua kriteria "Desain dari prosedur pemesanan" (G: 0.57, B: 0.60) dan "Modelmodel dan metode-metode penetapan harga" (G: $0.30, \mathrm{~B}: 0.55)$ terlihat prosedur pemesanan cukup kompleks pada kedua situs web tersebut.

- Pada Settlement Phase, ketiga kriteria yang termasuk dalam fase ini penting menurut asesor (skor 1.35). Skor per kriteria berturut-turut situs web balaipustakaonline.com, erlangga.co.id, kutukutubuku.com, dan gramediaonline.com adalah sebagai berikut: kriteria "Integrasi dari layanan-layanan umum" (B: 0.00, E: 0.27, K: 0.46 , G: 0.18), "Integrasi dari aplikasi-aplikasi e-commerce" (B: -0.08, E: 0.27, K: 0.37, G: 0.17 ), "Perutean dan penelusuran" (B: $-0.08, \mathrm{E}$ : $0.08, \mathrm{~K}: 0.46$, G: -0.18). Kriteria "Integrasi dari aplikasi-aplikasi e-commerce" menurut asesor tidak relevan untuk sektor penjualan buku online di Indonesia.

- Pada After-Sales Phase menurut asesor kedua kriteria dalam fase ini penting (skor 1.42). Nilai terendah diperoleh gramediaonline.com untuk kriteria "Akses kepada dukungan pelanggan" (skor 0.04) dan "Kinerja dari dukungan pelanggan" (skor -0.14). Asesor menilai kedua kriteria ini tidak banyak diperhatikan oleh pelaku bisnis online, meskipun menurut asesor kriteria ini penting dalam mendukung transaksi online.

- Pada Community Component terdapat empat kriteria yang berada dalam fase ini. Asesor menilai bahwa fase ini tidak terlalu penting untuk sektor penjualan buku online di Indonesia (skor 0.68). Perbandingan skor setiap kriteria berturutturut untuk balaipustakaonline.com, erlangga.co.id, kutukutubuku.com, dan gramediaonline.com sebagai berikut: kriteriakriteria "Akses ke sebuah komunitas virtual" (B: -0.21, E: 0.15, G: -0.40, K: 0.17), "Keuntungan dari relasi-relasi di dalam komunitas" (B: -0.07 , E: -0.03, G: -0.22, K: 0.27 ), "Keuntungan dari ketersediaan isi di dalam komunitas" (B: -0.21, E: 0.40, G: -0.22, K: 0.14), dan "Pemberdayaan pelanggan yang dihasilkan dari komunitas" (B: -0.26 , E: 0.17, G: $-0.11, \mathrm{~K}: 0.10)$. Rendahnya nilai pada empat kriteria ini tidak terlalu mempengaruhi kinerja dari aplikasi e-commerce, karena ekspektasi konsumen pada fase ini juga rendah.
- Pada Final Section, terdapat tujuh kriteria yang tercakup yaitu "Ketersediaan sistem", "Desain dari antarmuka pengguna", "Meningkatkan produktivitas dengan menghemat waktu", "Interaksi", "Fungsi-fungsi personalisasi", "Kepercayaan dari rekan bisnis (pemasok)", dan "Hal yang dapat dipercaya dari situs web dan situasi legal", seluruh asesor menilai penting fase ini, gramediaonline.com memperoleh nilai yang tinggi pada kriteria "Kepercayaan dari rekan bisnis (pemasok)" (skor 1.04), dan "Hal yang dapat dipercaya dari situs web dan situasi legal" (1.10). PT. Gramedia adalah penerbit dan penjual buku yang bekerja sama dengan banyak penerbit lain sehingga kedua kriteria tersebut harus tinggi, sedangkan toko buku online kutukutubuku.com memperoleh skor yang mendekati baik pada kriteria "Hal yang dapat dipercaya dari situs web dan situasi legal" (0.95). kutukutubuku.com juga memperoleh nilai tertinggi antara kompetitorkompetitornya pada empat kriteria pertama, "Ketersediaan sistem" (skor 0.81), "Desain dari antarmuka pengguna" (skor 0.93), "Meningkatkan produktivitas dengan menghemat waktu” (skor 0.93), dan “Interaksi” (skor 0.81).

\subsection{Evaluasi Strategi}

Evaluasi strategi yang dianalisis pada makalah ini hanya pada situs web balaipustakaonline.com karena keterbatasan jumlah halaman yang ditentukan.

Tabel 4 Satu set data yang teragregasi dengan peringkat penting: balaipustakaonline.com

\begin{tabular}{|c|c|c|c|c|c|c|}
\hline \multirow{3}{*}{$\begin{array}{l}\text { Hasil (Jangkauan }-2 /+2 \text { ) } \\
\text { Fase }\end{array}$} & \multirow{3}{*}{ Importance } & \multicolumn{3}{|c|}{ Company Profile } & \multirow{3}{*}{$\begin{array}{l}\text { Best Practice } \\
\text { Profile } \\
\text { (BPP) }\end{array}$} & \multirow{3}{*}{$\begin{array}{l}\text { Sector } \\
\text { Profile } \\
\text { (SCP) }\end{array}$} \\
\hline & & & \multicolumn{2}{|c|}{ Selisih } & & \\
\hline & & & $\mathrm{BPP}$ & SCP & & \\
\hline Information Phase & 1.47 & 0.46 & -0.41 & -0.36 & 0.87 & 0.82 \\
\hline Agreement Phase & 1.45 & 0.58 & -0.45 & -0.28 & 1.03 & 0.86 \\
\hline Settlement Phase & 1.35 & 0.00 & -0.52 & -0.47 & 0.52 & 0.47 \\
\hline After-sales Phase & 1.42 & 0.18 & -0.23 & -0.23 & 0.43 & 0.41 \\
\hline Community component & 0.74 & -0.27 & -0.52 & -0.37 & 0.25 & 0.10 \\
\hline Final Section & 1.47 & 0.48 & -0.40 & -0.38 & 0.88 & 0.86 \\
\hline Overall Score & na. & 0.31 & -0.42 & -0.36 & 0.73 & 0.67 \\
\hline
\end{tabular}



Gambar 6 Perbandingan balaipustakaonline.com, BPP dan SCP dengan peringkat penting 


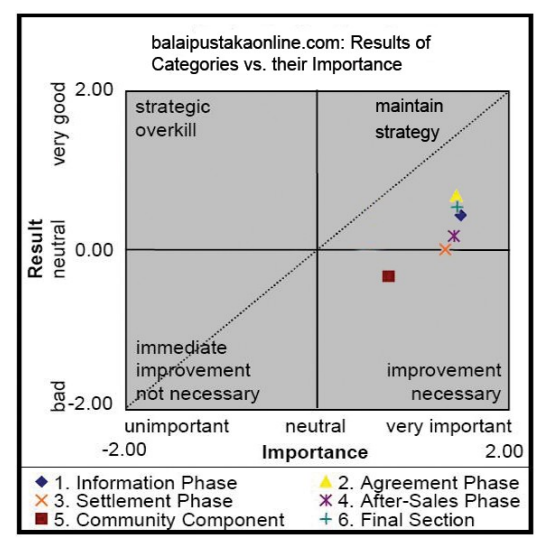

Gambar 7 Evaluasi strategi balaipustakaonline.com

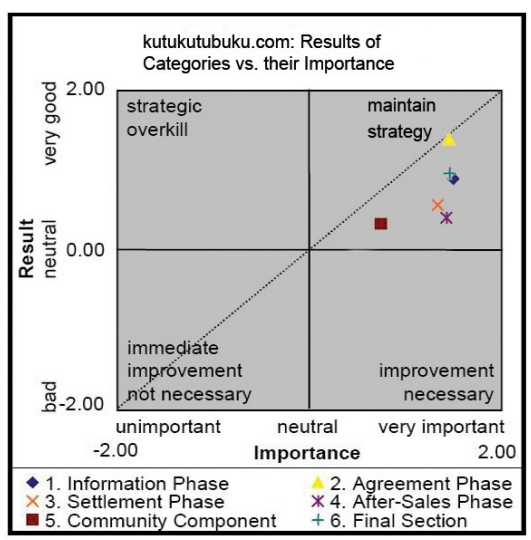

Gambar 8 Evaluasi strategi Best Practice Profile

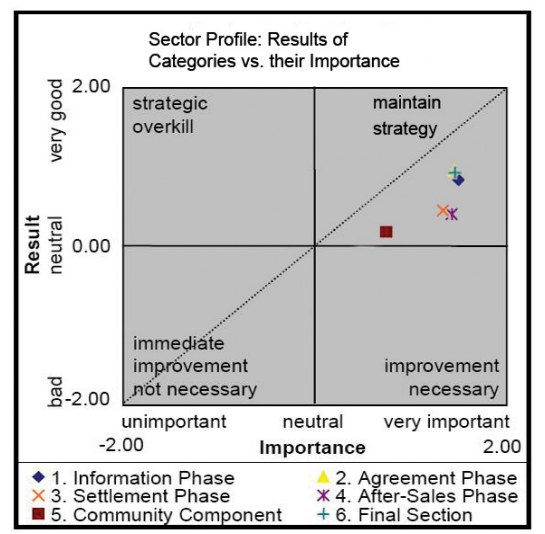

Gambar 9 Evaluasi strategi Sector Profile

Gambar 7 memperlihatkan evaluasi strategi balaipustakaonline.com dibandingkan dengan BPP (Gambar 8) dan SCP (Gambar 9). Secara ideal setiap fase seharusnya berada pada posisi diagonal atau mendekati garis diagonal. BPP secara keseluruhan setiap fasenya berada pada maintain strategy, hanya satu fase yang mendekati diagonal yaitu Agreement Phase (1.03), sementara itu fase-fase lainnya menjauhi diagonal, meskipun demikian skor per fase dan skor keseluruhan lebih tinggi dibandingkan balaipustakaonline.com. Profil SCP keseluruhan fasenya menjauhi diagonal, fase-fase yang penting menurut asesor yaitu Settlement Phase, After-Sales Phase dan Community component memperoleh skor jauh kurang dari separuhnya skala satu $(<1)$. Temuan ini mengindikasikan bahwa rata-rata kriteria situs web lokal yang tercakup dalam fase-fase tersebut tidak memiliki kinerja yang baik. Berdasarkan grafik, balaipustakaonline.com posisi setiap fasenya sangat menjauhi diagonal, Community Component berada di wilayah strategi improvement necessary, sedangkan Settlement Phase berada pada titik yang netral artinya posisi ini juga tidak mengindikasikan keadaan yang baik terpenuhinya kriteria sesuai ekspektasi konsumen. Jika dilihat lagi per kriteria "Integrasi dari layanan-layanan umum" (skor 0.00), "Integrasi dari aplikasi-aplikasi e-commerce" (skor -0.08), dan "Perutean dan penelusuran" (skor 0.08), kriteria-kriteria ini harus diperbaiki segera, agar ekspektasi konsumen bisa tercapai. Secara umum penilaian situs web balaipustakaonline.com belum memenuhi ekspektasi dari konsumen.

\section{KESIMPULAN}

Kesimpulan yang kami peroleh dari hasil analisis detail memperlihatkan bahwa keempat situs web lokal yaitu balaipustakaonline.com, erlangga.co.id, gramediaonline.com, dan kutukutubuku.com belum memenuhi ekspektasi dari konsumen-konsumen di Indonesia.

\section{PUSTAKA}

Asia Foundation (2002). SMEs and E-Commerce.

Diakses pada 16 Oktober 2009 dari

http://asiafoundation.org/pdf/SMEsurvey_Indo.p df.

Kurnia, S. dan Schubert, P. (2004). An Evaluation of On-line Grocery Services in Australia from a Consumers' Viewpoint. Proceedings of the Twelfth CollECTeR Workshop on eCommerce, 7./8. May, 2004, Adelaide, Australia. Diakses pada 10 Oktober 2009 dari http://bas.unikoblenz.de/bas/publications.nsf/c5afffd09db54d8 9c12572180036e1b1/29e57225ac2257f0c12573 59004908a7/\$FILE/Collecter2004 final.pdf.

Leimstoll, U., Kurnia, S., dan Schubert, P. (2005). Selling Books Online: An Evaluation of Australian and Swiss E-Shops, Proceedings of the 18th Bled eConference, eIntegration in Action, Bled, Slovenia, June 6-8 2005.

Diakses pada 10 Oktober 2009 dari http://bas.uni-

koblenz.de/bas/publications.nsf/c5afffd09db54d8 9c12572180036e1b1/833f1801ba656351c12573 59004908ce/\$FILE/40_Leimstoll_Kurnia_Schub ert.pdf.

Merwe, R. dan Bekker, J. (2003). A Framework and methodology for evaluating e-commerce Web 
sites. Internet Research; 2003; 13, 5; ABI/INFORM Global. pg. 330.

Diakses pada 10 November 2009 dari http://proquest.umi.com/pqdweb.

Schubert, P. (2003). Extended Web Assessment Method (EWAM)-Evaluation of Electronic Commerce Applications from the Customer's Viewpoint, in: International Journal of Electronic Commerce, Vol. 7, No. 2, Winter
2002-2003. Diakses pada 12 November 2009 dari http://bas.unikoblenz.de/bas/publications.nsf/a3f18119c0cb8fe 3c12572180036eb5c/5f4066937bf8a021c125735 9004908cc/\$FILE/schubert_ijec_2003.pdf.

World Internet Users and Population Stats. Diakses pada $\quad 14 \quad$ September 2009 dari http://www.internetworldstats.com/stats.htm. 